working in cities and towns of this country will find in the book, a valuable guide in carrying out the details of their duties and in advising their local authorities regarding improvement of sanitation and public health of their towns.

\section{B. B. B.}

FOOD AND THE PRINCIPLES OF DIETETICS.-By $R$. Hutchison, M.D., F.R.C.P., and V. H. Mottram, M.A. Seventh Edition. London: Edward Arnold and Co., 1933. Pp. xvi plus 630. Illustrated. Price, $21 \mathrm{s.}$

Dr. Hutchison's name as a keen physician and a gifted clinical teacher is too well known in medical circles to need any special introduction. His book on 'Food and the Principles of Dietetics' was first published in the year 1900, and for the last 32 years it has successfully maintained its position as a standard work of reference on the subject. Our ideas on dietetics have undergone very extensive changes during recent years particularly on account of the recognition and isolation of the vitamins. In order to keep pace with this increase of knowledge the author has collaborated with Professor Mottram, and their joint efforts are represented in the seventh edition. This edition has been extensively revised and reset. The first three chapters have been completely re-written through the help of Professor Mottram. The coloured plates showing the food values of the commion articles of food are novel features and are especially instructive. The new edition, we are confident, will not only maintain its well-earned popularity, but will enhance the prestige of its predecessors.

\section{R. N. C}

ANATOMY OF THE EYE AND ORBIT. INCLUDING THE CENTRAL CONNECTIONS, DEVELOPMENT, AND COMPARATIVE ANATOMY OF THE VISUAL APPARATUS.-BY E. Wolff, M.B., B.S. (Lond.), F.R.C.S. (Eng.). London: H. K. Lewis and Co., Ltd., 1933. Pp. viii plus 310, with 173 illustrations. Price, 31s. 6d.

THIs book will naturally appeal only to the specialist whose interest in anatomy does not extend beyond the orbit and its contents. It is beautifully illustrated, most of the figures being original, and the book is printed on heavy art paper. It is altogether a pleasing production and is a credit to both author and publishers, and the reviewer's only regret is that he cannot recommend it to the general medical public. The reasons of this are, that although the price is high when one considers the limited scope of the book it is not too much if the form of presentation of the subject is the criterion of its value; but when the reader can acquire nearly all the information given in the volume together with the anatomy of all the rest of the body for the expenditure of only a little more money, this book must be classed as a luxury and not a necessity to the profession at large.

MODERN PHARMACOLOGY AND THERAPEUTIC GUIDE.-By Akhil Ranjan Majumder, M.B. Published by S. P. Majumder, Calcutta. Third Edition. Pp. viii plus 602. Price, Rs. 5. (O'btainable from the Book Company, Ltd., Calcutta.)

Thrs book was first published in 1929 to provide a handy manual to the students going up for the licentiate standard of the State Medical Faculty examinations. That the book has served its purpose and is a certain answer to the expressed need of the students is more than evident from the rapidity with which two editions were consumed and a third edition called for. The science of therapeutics and pharmacology is fast progressing and a good many additions have naturally been made to keep the book up to date. Amongst the important additions may be mentioned the chapters on immune therapy, on preparations of invalid foods, on the calorific and vitamin values of various food-stuffs in common use in India, and on radiotherapy. In writing the last-named chapter, the author has obtained the services of a radiologist and technician. The numerous prescriptions appended in the footnote are features which cannot be passed by without comment. The beginner will appreciate it thoroughly in view of the fact that difficulties are usually met with in writing out a good recipe.

The book, we have little doubt, will be of assistance to those who have to revise rapidly their knowledge of pharmacology and therapeutics in general. To the worried student whose final examinations are within sight, the book will be a sympathetic friend. It should not, however, be forgotten that it is a sort of a synopsis of the vast subject of pharmacology and therapeutics, and cannot replace a standard and authoritative textbock; any attempt to make it serve this purpose will inevitably lead to failure.

\section{MELIODOSIS.-By A. T. Stanton, C.M.G., M.D., F.R.C.P., and William Fletcher, M.D., M.R.C.P. London: John Bale, Sons and Danielsson, Ltd., 1932. Pp. .iv plus 59, with 37 plates.}

ThIs is No. 21 of the studies from the Institute for Medical Research, Federated Malay States, and deals with the very deadly and fortunately rare disease Meliodosis. It was first reported in the Indian Medical Gazette in 1912 by Whitmore and Krishnaswami and since then of the 83 recorded cases only two have recovered and a correct diagnosis has been made before death in only nine cases. That the clinical diagnosis of meliodosis is difficult is well illustrated by the different diagnoses such as cholera, dysentery, enterie fever, malaria, amœbic abscess of the liver, smallpox, and glanders that have been made in cases of meliodosis. The Malay States, Ceylon and the Dutch East Indies are the only countries where meliodosis is known to attack animals and although cases of human infection have been so far reported from Burma and the Malay States only, we agree with the authors when they state that it is highly improbable that meliodosis is limited to the few places where its presence has been detected. Its symptoms are so varied and obscure that it is seldom diagnosed until after death, and then only in those places where a bacteriological examination can be made. Even when laboratory facilities are available the disease may escape recognition by those who are unfamiliar with it, because the bacillus grows so profusely that it is apt to be mistaken for a contamination.

The authors have dealt exhaustively with the clinical, pathological and bacteriological aspects of the disease in which they have been interested for a number of years. The illustrations which make up more than half the volume are a remarkable feature of this well prepared book.

This account of meliodosis should be in the hands of everyone who practises in the tropics and it is very probable that it will lead to the recognition of meliodosis in many parts of the world. This book will prove invaluable in laboratories engaged in the investigation of tropical diseases.

$$
\text { C. L. P. }
$$

DISEASES OF THE EYE.-By Ernst Fuchs. The 15th German Edition as revised by Professor $M$. Salzmann. Translated into English by E. V. L. Brown, Professor of Ophthalmology, University of Chicago. This is the 10th Edition in English. It has 255 illustrations and 41 coloured plates. Philadelphia and London: J. B. Lippincott Company, 1933. Pp. xviii plus 641 , with 255 illustrations in the text and $\mathbf{4 1}$ coloured figures. Available from Messrs. Butterworth and Co. (India), Ltd., Calcutta. Price, Rs, 31-8.

'Fuchs' Ophthalmology' has been a household word to ophthalmologists for over 44 years. Each succeeding edition got larger and larger, as is usual, till the last edition became altogether too unwieldy. The present volume has been reduced by some 350 pages by the omission of the Introduction and the chapters on Examination of the Eye, Refraction, and Operátions, 